\title{
土壌埋設型センサーによる茶園の施肥管理技術
}

静岡県茶業試験場*

岩橋光育

(平成 8 年 12 月 26 日受理)

\section{Technique of Fertilizer Administration in Tea Field by Soil Buried Sensor}

\author{
Mitsuiku IWAHASHI \\ Shizuoka Tea Expreiment Station
}

近年, 生活水準の向上により良質茶の需要 が高まり，これに応えるべく良質茶生産のた めに, 多肥栽培（窒素 100〜 $120 \mathrm{~kg} / 10 \mathrm{a}$ ）が 行なわれている。このような多肥栽培は, 根 量の減少, 根の活性低下だけでなく, 耐病性, 耐寒性の低下など茶樹を脆弱化させこれが 品質や収量に悪影響を及ぼすことが心配され ている。また，茶価の伸び恼みとあわせ肥料 費が経営収益率を低下させる大きな要因と なっている。さらに, 省資源, 環境污染防止 の上からも多肥問題は全国共通の問題となっ ている。

このため，過剩な施肥を削減し，なおかつ 健全な茶樹の育成により生葉品質问上と収量 増加をめざす必要があり, 従来の栽培暦に準 じた施肥にかわり，茶樹の生育周期に応じて 必要な養分を必要な量だけ供給する施肥技術 が求められている。

この問題を解決するための一つの方法とし て，土壤埋設型センサーの情報によるパソコ ンを利用した施肥管理技術の確立が有効であ ると考えられる。この技術の確立のためには, (1)茶園での各種センサーの使用方法, (2)窒素 成分の形態変化及び下層への移動速度の解 明, (3)生育周期に応じた土壤目標窒素濃度の 策定, (4)目標窒素濃度に基づき, 施肥時期及
び施肥量を的確に判断する施肥管理ソフトの 作成，さらに(5)作成したソフトに基づいた施 肥管理による生葉の収量, 品質への効果の確 認を行う必要があり,これらについて検討し たので紹介する。

\section{1 各種センサーの使用方法}

1. 1 E Cセンサー測定值と土壤無機態窒 素濃度との関係 ${ }^{1}$

土袞理設型センサーを利用して土壤中の窒 素成分の濃度把握を試みるために，3 種類の 土壤について, EC センサー(侏藤原製作所製 SPAD-2121) の測定値と土壌無機態窒素濃度 との関連性を調査した。

赤黄色土, 黒ボク土については静岡県下か ら各 100 点, 褐色森林土については岐阜県下 から 75 点採取した。土䁃はうね間(梁さ： 5 〜 15 と 15 20 cm の 2 層) から採取し, 風乾 後, $2 \mathrm{~mm}$ のふるいを通し試験に供試した。 $\mathrm{EC}$ 測定は土壤水分が $\mathrm{pF} 1.5$ になるように 加水, 調整し密閉後恒温室 $\left(5^{\circ} \mathrm{C}\right)$ 内で 1 日間 安定化させ, 取り出した土壤に ECセンサー を㨉入し， 3 時間後に計測した。

その結果, 赤黄色土の $\mathrm{pF} 1.5$ における $\mathrm{EC}$ センサー測定值と無機態窒素濃度 $(\mathrm{mg} / 100$ g) との間には, 図 1 に示したとおり0.9以

* 439 静岡県小笠郡菊川町倉沢1706-1.1 


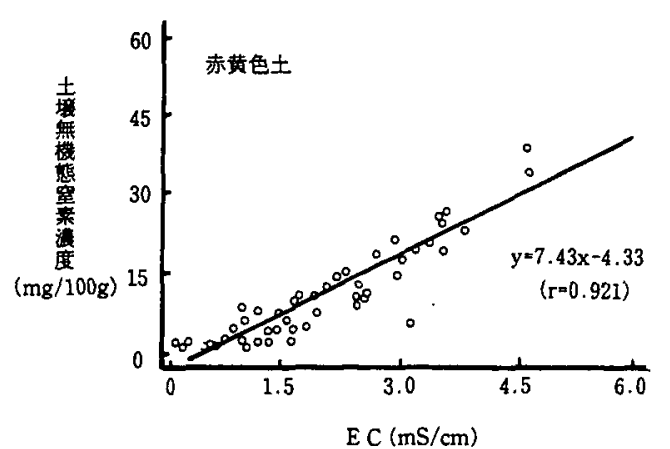

図 1 E C センサー測定值と土壤無機態窒素濃 度の関係

上の高い相関関係が認められた。また，他の 二つの土壤についても同様の結果であった。 無機態窒素濃度と EC センサー測定値との関 係式は, 無機態窒素濃度を $\mathrm{y}, \mathrm{EC}$ センサ一測 定值 $(\mathrm{m} \mathrm{S} / \mathrm{cm})$ をとすると, 黒ボク土で は $\mathrm{y}=7.79 \mathrm{x}-1.22$, 赤黄色土では $\mathrm{y}=7.43$ $\mathrm{x}-4.33$ ，褐色森林土では $\mathrm{y}=6.74 \mathrm{x}-0.20$ であった。

次に, EC センサー測定値は同一土壌でも 土壤水分の違いにより変化する。そこでセン サーを利用してより正確な無機態爫素濃度を 把握するのために，土壤含水率の違いが $\mathrm{EC}$ センサーの測定值に及ぼす影響を調查した。 赤黄色土についての結果は図 2 に示すとおり で, EC 值は土壌含水率の增加にともない直 線的に低下する傾向が認められた。また, EC 値の隇少は各土壤ともに, EC が高い土壌ほ ど大きく，ECが低い土壌ほど小さくなる傾 向が認められた。

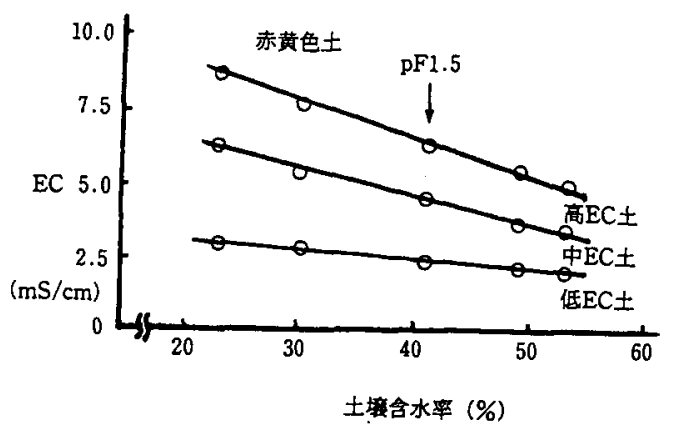

図 2 土㙴含水率の違いによるE C センサー測 定値の变化
そこで,これらの関係を利用して剆定した $\mathrm{EC}$ 值を $\mathrm{pF} 1.5$ 状態の EC 值に補正するこ とを試みた。まず, 赤黄色土の含水率(侏) エー・エス・ディー製非定常線熱源ヒートプ ローブ型水分センサーを使用）と EC 值のプ ロットを図 2 に落として高 EC 土に対する割 合 (傾き, 含水率の増加による EC 值の減少程 度）と，プロットを通る補正式（一次式）を 試算した。この式に $\mathrm{pF} 1.5$ の含水率を代入す ることにより，赤黄色土の測定時の EC 值を $\mathrm{pF} 1.5$ 状態の EC 值に補正することが可能 となった。

次に土溒の無機態窒素濃度の推定は, 得ら れた $\mathrm{pF} 1.5$ 状態の補正 EC 值を図 1 におけ る無機態窒素濃度 $\mathrm{y}$ と EC 值 $\mathrm{x}$ の関係式に代 入することにより可能と考えられた。

以上の結果をふまえ EC センサー測定值と 土壌含水率から土壤中の無機態窒素濃度を推 定するための推定式を 3 土壌について以下の ように作成した。式中の（）の中は測定 EC 値を PF 1.5 状態の EC 值に補正するための 式である。

土袞中無機態窒素濃度の推定式

$\mathrm{A}=$ 推定無機態窒素濃度 $(\mathrm{mg} /$ 土 $100 \mathrm{~g})$

$\mathrm{B}=\mathrm{EC}$ センサー測定值 $(\mathrm{m} \mathrm{S} / \mathrm{cm})$

$\mathrm{C}=$ 土壤含水率（\%）

(1) 赤黄色土

$\mathrm{A}=7.43 \times\left(\frac{-0.121 \times(41.0-\mathrm{C})}{(-0.121 \times \mathrm{C}+11.428)}+1.0\right) \times \mathrm{B}-4.330$

(2) 黒ボク土

$A=7.79 \times\left(\frac{-0.096 \times(55.5-C)}{(-0.096 \times C+14.024)}+1.0\right) \times B-1.220$

(3) 褐色森林土

$\mathrm{A}=6.74 \times\left(\frac{-0.106 \times(45.0-\mathrm{C})}{(-0.106 \times \mathrm{C}+16.872)}+1.0\right) \times \mathrm{B}-0.200$

なお，土壌毎の推定式による無機態窒素濃 度のデー夕は，3枚のマトリックスにして施 肥管理ソフトに組み込んだ。

1 . 2 センサーの設置方法

次に, 茶園全体の養分状態を把握する方法 
茶業研 究 報

について検討した。土壇はもともと物理的に も化学的にも不均質なものであり, 異なった 状態で生成され集合し，さらに経時的に絶え ず変化しており，これらの把握方法はそう簡 単ではない。

センサーによる測定では, 従来の土壤採取, 調整方法 ${ }^{2)}$ は異なり問題となるのはセン サーの感知部と土壤との接地面積が EC セン サーで $0.95 \mathrm{~cm}^{2}$, 水分センサーで $7.79 \mathrm{~cm}^{2}$ と あまりに小さいために, 測定しょうとする茶 園の代表值を得るための EC センサーと水分 センサーの埋設本数が土壤の採取点数に比べ て多くなる傾向にあることである。そこでで きるだけ少ないセンサーの本数で苯園の EC 及び水分の代表值を得る設置方法を検討し た。

(1) EC センサーの埋設の部位と深さ3)

$\mathrm{EC}$ センサー及び水分センサーの埋設の部 位や深さなどについて検討を行った。ECセ ンサーの埋設部位や深さは作物や目的によつ て異なるが，一般的には肥料成分と作物の生 育が最も密接に関係している位置にセンサー を埋める必要がある。

そこで，適正な埋設部位を明らかにするた めECセンサーをうね間と雨落ち部に埋設 し，その応答性ついて検討を行なった。その 結果, EC センサーの応答性は施肥部位であ るうね間が雨落ち部にくらべて大きく,また, 施肥に対する応答性が良好であった。

次に, う齐間中央の媣さの違い $(10 \mathrm{~cm}, 20$ $\mathrm{cm}, 30 \mathrm{~cm})$ と $\mathrm{EC}$ センサーとの応答性を調查 したところ， $20 \mathrm{~cm}$ 及び $30 \mathrm{~cm}$ の深さに埋設 した場合は両者とも調查期間（1 年間）を通 じて測定できたが, $10 \mathrm{~cm}$ の深さでは土壌水 分が $\mathrm{pF} 2.5$ 程度になるとセンサー先端での 土裹溶液量不足により測定できない場合が認 められた。また, 施肥に伴う EC センサー測定 值の変化は, 深さ $10 \mathrm{~cm}$ で大きく, $20 \mathrm{~cm}, 30$ $\mathrm{cm}$ では小さかった。

以上のことを考慮して茶園の養水分の状態 を把握するためのセンサーの埋設場所と深さ は，うね間中央部の梁さ $20 \sim 30 \mathrm{~cm}$ に埋設す ることが適当であると考えた。
（2）EC センサー及び水分センサーの埋設本 数 ${ }^{3)}$

$\mathrm{EC}$ センサー及び水分センサーによる養水 分の状態把握のため最も効率的な埋設本数や 埋設方法について検討した。

EC センサーを供試し, 静岡県茶業試験場 内の赤黄色土茶園 (面積: 10 a $(20 \mathrm{~m} \times 50 \mathrm{~m}$ ), うねの方:南北) 及び隣接する黒ボク土茶園 (面積： $10.4 \mathrm{a}(26 \mathrm{~m} \times 56 \mathrm{~m}$ )，う放の方 向：南北）の同一のうね間にそれぞれ $4 \mathrm{~m}$ 間 隔で 5 本, う放方向に対して直角に $9 \mathrm{~m}$ 間隔 で 5 本，計 25 本をうね間の中心部の梁さ 20 $\mathrm{cm}$ に格子状に埋設し， $\mathrm{EC}$ 及び土壤含水率を 計測した。

次に, 無作為に抽出した測定值について埋 設本数の違いによる測定値の平均値の変動係 数は赤黄色土茶園ではセンサーの埋設本数 3 本，5本及び7本で各々 $13 \% ， 9 \% ， 7 \%$, 黒ボク土茶園では各々 $17 \%, 13 \% ， 9 \%$ と本 数が多くなるほど小さくなる傾向が認められ た。

田中4はバッグカルチャのかん注方式の養 液栽培における全体を把握するための ECセ ンサーの必要本数は 10 a 当たり $5 \sim 10$ 本で あると報告している。

この報告に照らすと赤黄色土茶園では 5 本, 黒ボク土では 7 本程度埋設すればほ場を 代表する EC 值が得られると考えられる。し かし，センサー測定時の煩雑性や経費を考慮 するとセンサーの埋設本数をさらに減らす必 要があり,そのための埋設方法について検討 を行った。

まず，茶園ではうね間に施肥を行うという 特殊性に鑑み，埋設方向の違いによる変動係 数の変化をみるため, センサーの測定值の取 り扱いを無作為ではなく，うね間の格子状の 25 の測定值を 4 方向 (東西(うね間に対して 直角方向), 南北, 南東及び北東了に测定值 ( 5 本）毎に平均を求め，その変動を調查した。

その結果は表 1 に示すように，うねに対し て直角に埋設した（東西方向）場合の測定值 ( 5 本) 毎の平均値の変動係数が赤黄色土茶 園及び黒ボク土茶園で各々 6 ，5\%, 南北方 
土䫓埋設型センサーによる茶園の施肥管理技術

表 1 平坦地におけるECセンサーの配置方法

\begin{tabular}{|c|c|c|c|c|c|c|c|c|c|c|}
\hline \multirow{4}{*}{ 解析方向 } & \multicolumn{5}{|c|}{ 赤黄色土茶園（静岡茶試） } & \multicolumn{5}{|c|}{ 黒ボク土茶園（静岡茶試隣接） } \\
\hline & \multicolumn{3}{|c|}{$\begin{array}{l}\text { 測定値の平均值 } \\
(5 \text {, } \mathrm{mS} / \mathrm{cm})\end{array}$} & \multirow{3}{*}{$\begin{array}{c}\frac{\text { 同左の }}{\text { 平均値 }} \\
0.50\end{array}$} & \multirow{3}{*}{$\begin{array}{c}\begin{array}{c}\text { 同左の変 } \\
\text { 動係 } \\
(\%)\end{array} \\
6\end{array}$} & \multicolumn{3}{|c|}{$\begin{array}{l}\text { 測定值の平均値 } \\
(5 \text { 本、 } \mathrm{mS} / \mathrm{cm})\end{array}$} & \multirow{2}{*}{$\begin{array}{c}\text { 同左の } \\
\text { 平均値 } \\
1.63\end{array}$} & \multirow{2}{*}{ 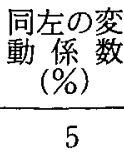 } \\
\hline & 0.47 & 0.46 & 0.51 & & & 1.77 & 1.61 & 1.55 & & \\
\hline & 0.54 & 0.50 & & & & 1.66 & 1.57 & & & \\
\hline \multirow{2}{*}{ | 南北 } & 0.44 & 0.45 & 0.55 & 0.49 & 12 & 1.38 & 1.14 & 1.87 & 1.63 & 21 \\
\hline & 0.46 & 0.57 & & & & 1.95 & 1.82 & & & \\
\hline \multirow{2}{*}{ \南東 } & 0.49 & 0.52 & 0.51 & 0.50 & 4 & 1.63 & 1.80 & 1.83 & 1.63 & 10 \\
\hline & 0.50 & 0.46 & & & & 1.51 & 1.40 & & & \\
\hline \multirow{2}{*}{ ／北東 } & 0.43 & 0.58 & 0.51 & 0.49 & 12 & 1.52 & 1.45 & 1.66 & 1.63 & 11 \\
\hline & 0.45 & 0.50 & & & & 1.83 & 1.67 & & & \\
\hline 全体(25本) & \multicolumn{3}{|c|}{0.49} & & & \multicolumn{2}{|c|}{1.63} & & & \\
\hline 满 考 & \multicolumn{5}{|c|}{ 面積 $1,000 \mathrm{~m}^{2}$ （うね長 $20 \times 50 \mathrm{~m}$ ) } & \multicolumn{5}{|c|}{ 面積 $1,456 \mathrm{~m}^{2}$ (うね長 $26 \times 56 \mathrm{~m}$ ) } \\
\hline
\end{tabular}

向で $12,21 \%$, 南東方向で $4,10 \%$, 北東方

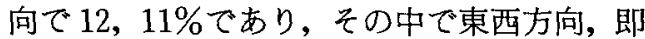
ちうねに対して直角に埋設して得られた測定 値 ( 5 本) 平均値のばらつきが最も少ない傾 向が認められ，全体平均值〔測定値の数 25, 赤黄色土茶園：0.49 m S/cm（変動係数 $23 \%$ ), 黒ボク土茶園 : $1.63 \mathrm{~m} \mathrm{~S} / \mathrm{cm}$ (変動係 数 $29 \%$ ) に対する安定した平均值を得るた めの計測法としてはうねに対して直角に埋設 するのが適当と考えられた。

さらに，うねに対して直角に埋設した場合 の, 埋設本数と測定值の平均値の変動係数と の関連を調査した結果を図 3 に示す。

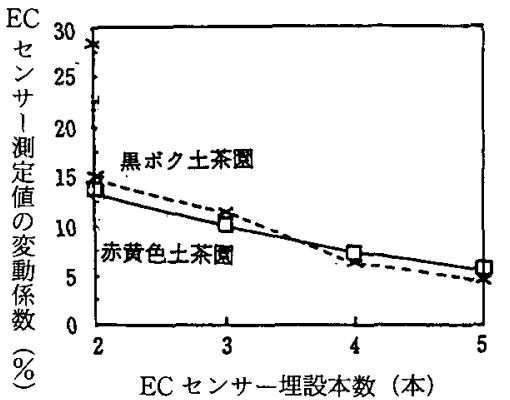

図 $3 E C$ センサ一の埋設本数と測定值平均值 の変動係数

注）うねに対して直角に解析
センサーを $2 \sim 5$ 本埋設した場合の平均値 のばらつきを調查したところ，赤黄色土茶園 では変動係数は $2 ， 3 ， 4 ， 5$ 本で各々 $13 \%$, $10 \%, 7 \%, 6 \%$, 黒ボク土茶園では各々 $14 \%$, $11 \% ， 6 \% ， 5 \%$ あり，無作為に測定值を 処理した場合にくらべて変動係数は低かっ た。

柳沢ら ${ }^{5}$ は確率 $75 \%$ にお ける所定目標精度 （信頼区間の幅／真の值 \%) と測定值の変 動係数からサンプルの採取にあたり個体数を 決定する表を作成した。すなわち採取しよう とするほ場の変動係数を知れば任意の目標精 度に応じた試料採取数を決定することが可能 であると報告している。

茶園を代表する $\mathrm{EC}$ 值を得ようとする場合 の精度は定まっていないが, 茶園が不均一で あることを考慮しても目標精度は少なくとも 20２5\%以下に抑えたいと考えた。さらに $\mathrm{EC}$ センサーの剆定値の平均值の変動計数を $10 \%$ 以下とするとこの表から採取個体数は 4 本程度が妥当ではないかと判断した。これら の結果から，平坦地における茶園の養分状態 を把握するための EC センサーの埋設本数と しては，うねに対して直角方向に 4 本うね間 の中央の哚さ $20 \mathrm{~cm}$ に埋設するのが適当と 
考えられた。

また，水分センサーの埋設方法についても EC センサーと同様に設置し調査した。その 結果，平坦地に抢いて茶園の土壤水分状態を 把握するための水分センサーの必要配置本数 は概ね 2 本で EC センサーの近くに設置する のが妥当と考えられた。

\section{2 茶園における窒素成分の形態変化及び 移動速度の解明}

有機質肥料の分解や下層への移動を予測す るためには，施用した肥料の土壤微生物によ る無機化，その後の硝酸化成さらに下層への 移動を明らかにする必要がある。

\section{1 地温及び土壤水分量と窒素成分の形} 態変化の関連性の解明

有機質肥料の分解及び硝酸化成は，土壌の 種類, $\mathrm{pH}$ ，地温及び土壤水分量により大きな 影響を受ける。そこで，赤黄色土，黒ボク土 及び褐色森林土の土壌 $\mathrm{pH}$, 地温及び肥料の 種類の違いと窒素成分の形態変化の関連性を 調査した。供試土壌は 3 種類, 肥料は 8 種類 （硫安，硝安，尿素，なたね粕，魚粕，肉骨 粉, IB, CDU), 各土壤の $\mathrm{pH}$ は 3 段階 $(3.1$, $4.0,5.1)$, 地温は 3 段階 $\left(5,15,25^{\circ} \mathrm{C}\right)$ の 組み合わせで,窒素成分の形態変化を 90 日間 にわたり調查した。得られたデー夕は土壌（ 種類), $\mathrm{pH}$ ( 3 種類), 肥料 ( 8 種類) の組み 合わせ毎に 72 枚のマトリックスにして施肥

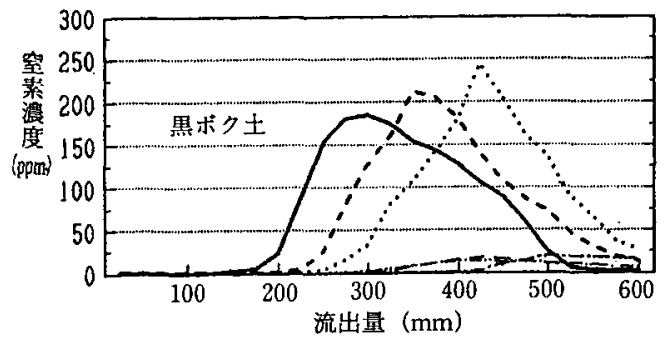

図 4 土壤の透水性の違いによる流出水の窒素 濃度の変化

\section{硝酸態窒素:}

一粗区 $\left(1.1 \times 10^{-2}\right)-$ 中区 $\left(1.1 \times 10^{-3}\right) \cdots \ldots$ 密区 $\left(1.3 \times 10^{-3}\right)$

アンモニア態窒罢

- - 粗区 $\left(1.1 \times 10^{-2}\right) \ldots . .$. 中区 $\left(1.1 \times 10^{-3}\right) \cdots$ 密区 $\left(1.3 \times 10^{-3}\right)$ 流出量: 降水量換算
管理ソフトに組み込んだ。その結果, $\mathrm{pH}$ が暴 なる土裹毎にある肥料を施用した場合，日悔 に地温が変化する条件下における施用した肥 料成分の日毎の硝酸化成による硝酸態窒素の 生成量の予測が可能となった。

2.2 透水性の違いが窒素成分の移動に及 ぽ影響6)

降雨による窒素成分の表層からセンサー部 位までの移動を経時的に予測するための基礎 データを得るために，カラム試験で透水性の 違いによる窒素成分の移動速度を調查した。

黒ボク土の透水性の違い（粗, 中, 密) に よるカラム底部からの流出水中の硝酸及びア ンモニア態窒素濃度の変化を図 4 に示した。 硝酸態窒素の変化をみると, 粗区（透水性： $\left.1.1 \times 10^{-2} \mathrm{~cm} / \mathrm{sec}\right)$ では流出量が $125 \mathrm{~mm}$ 程 度から増加し始めた後, 急激に増加し 300 mm で $186 \mathrm{ppm}$ と最高に達した後に, 緩やか

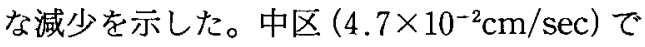
は $175 \mathrm{~mm}$ 程度から増加し始めた後, 急激な 增加を続け $350 \mathrm{~mm}$ で $212 \mathrm{ppm}$ と最高に達 した後, 以後減少した。密区 $\left(1.3 \times 10^{-3} \mathrm{~cm} /\right.$ $\mathrm{sec})$ では $200 \mathrm{~mm}$ 程度から增加し始めた後, 穏やかに増加し $425 \mathrm{~mm}$ で $244 \mathrm{ppm}$ と最高 に達した後に，穏やかな減少を示した。

このように, カラムからの流出水中の $\mathrm{NO}_{3}$ 一N濃度のピークは, 透水性が良好な土塆ほど 速く認められ，またそのピークの変化はゆる やかな傾向を示した。また， $\mathrm{NH}_{4}-\mathrm{N}$ 濃度の ピークも透水性が良好な土壌ほど速く認めら れるが，その濃度は $25 \mathrm{ppm}$ 以下と低く推移 した。これらのデータから土壤表面に, ある 1 日間に生成した硝酸態窒素量のその後の降 雨量の違いによる地表下 $20 \mathrm{~cm}$ での窒素量 の推定が可能となった。また，他の 2 土裹に ついても同様な結果が得られた。得られた データは土壌（3 種類）の違い毎に3枚のマ トリックスにして施肥管理ソフトに組み込ん だ。

\section{3 茶樹の生育周期に応じた土袞目標窒素 濃度の策定}

施肥管理を行う場合，施肥の要否の判断基 
準となる土壤目標窒素濃度を定める必要があ る。しかし目標窒素濃度は, 土壌類型, 栽培 形態，地形条件などにより異なる。

そこで，適正な施肥管理を行い高品質の生 葉を生産している農家を選び，黒ボク土，赤 黄色土, 褐色森林土について土壌毎に 7 ほ場

（農家 6 ほ場，茶試 1 ）について，施肥管理 状況, 土壌中無機態窒素濃度（月 3 回，採土 部位：う水間の深さ $15 〜 20 \mathrm{~cm}$ ）の推移を 1 年間調査した。無機態窒素の組成内訳をみる とアンモニア態窒素が $4 \sim 5$ 月にかけて 2 〜 3 割を占めることもあるが，それ以外はア ンモニア態窒素は少なく硝酸態窒素がほとん どを占めた。施肥管理の基準となる年間を通 じての目標窒素濃度は，調査した土壌中無機 態窒素濃度の平均值を 365 日間につなげ，さ らに 15 日間の移動平均により無機態窒素濃 度を算出し策定した。

策定した赤黄色土茶園における目標窒素濃 度は，図 5 に示すように1月〜2月にかけて は 7〜 $8 \mathrm{mg} / 100 \mathrm{~g}$ と低いが, 施肥に伴い, 3 月上旬から増加しはじめ 3 月下旬にかけて $30 \mathrm{mg}$ 程度まで高まる。さらに 4 月上旬〜 6 月中旬にかけて $30 \sim 35 \mathrm{mg}$ と高く推移し, 梅 雨時期である 6 月下旬〜 7 月中旬にかけて $30 \mathrm{mg}$ 以下となるが，これは降雨による肥料 の流亡に起因すると思われる。その後, 再び $30 \mathrm{mg}$ を越えた状態で推移し 10 月に入ると $30 \mathrm{mg}$ 以下となり，以後 11 月下旬まで漸減 し, 12 月以降は $10 \mathrm{mg}$ 以下で推移した。また, 他の 2 土壌についても同様な結果が得られ た。策定した目標窒素濃度は施肥に伴う窒素 だけでなく地力窒素からの無機化による供給 の合量と考えられる。

茶園の地力窒素について鈴木7は茶園土壌 の地力窒素からの無機化は 3 月から始まり, 6 月に最大となり以後低下し, 年間窒菜を 10 a あたり $80 \mathrm{~kg}$ 施用する場合，有機質肥料区 土㙵では最大, 窒素として $12 \mathrm{mg} / 100 \mathrm{~g}(10$ a 当たり換算 $11 \mathrm{~kg}$ ), 慣行肥料区の土壤では $5 \mathrm{mg} / 100 \mathrm{~g}$ (10 a 当たり換算 $6 \mathrm{~kg}$ ) 供給さ れることを報告している。このため施肥にあ たっては目標窒素濃度の確保のために施肥に
よる窒素の確保だけでなく, 地力窒素からの 供給も考慮に入れた施肥管理が必要と考え る。策定した目標窒素濃度は 1 枚のマトリッ クスにして施肥管理ソフトに組み込んだ。

\section{4 施肥管理ソフトの作成}

土袞埋設型センサーの情報を利用した施肥 管理のために, 各種センサ一の自動測定（ほ 場のデータロガとパソコンとは有線, もしく は無線で連絡), 測定值から無機態窒素濃度を 推定し, 生育周期に応じた目標窒素濃度を維 持するための施肥時期及び施肥量の判断可能 なパソコンを用いた施肥管理ソフトを作成し た。以下,ソフトの概要を示す。

(1) 表計算ソフトから本システム内のデータ ベースに変換できるソフトの開発

(1)センサーからのデータの入力 (EC, 土壤 含水率, 地温, 降水量),

(2)土㙥特性, 施肥暦及び目標窒素濃度の入 力 (土銮 $\mathrm{pH}$, 透水性, 有機物含量, うね幅, 施肥幅, 施肥暦, 肥料の種類とその組成)

(3)気象データの入力（過去 10 年間の地温, 土壤含水率, 降雨量, 蒸散量のデータ)

(4)有機質肥料の無機化及び硝酸化成データ （マトリックス）の入力

(無機化, 硝酸化成データ 土壤の種類, $\mathrm{pH}$, 地温, 肥料の種類)

(2) データ解析ソフトの開発

(1) EC, 水分センサー值からの土壤窒素濃 度推定ソフト（マトリックス）の作成

(2)有機質肥料の無機化速度及び硝酸化成子

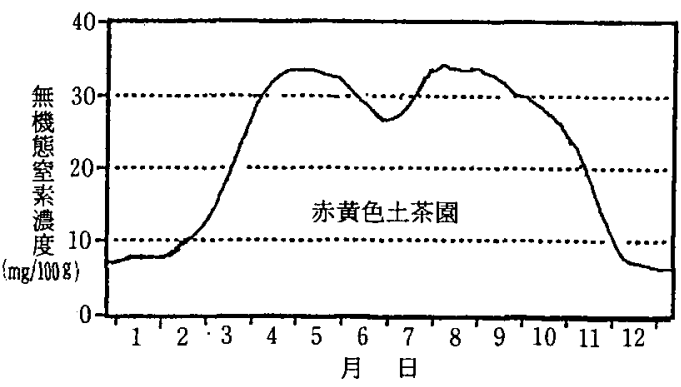

図 5 茶園における時期別目標窒素濃度の推移 部位：うね間深さ $20 \mathrm{~cm}$ 
測ソフト（マトリックス）の作成

土壌 $\mathrm{pH}$, 肥料, 地温每の硝酸化成で生成 する日毎の各々の窒素生成量推定

(3)透水によるセンサー部位における土埣中 窒素濃度予測ソフト（マトリックス）の作成

（3）以下の表示及び出力ソフトの開発

(1)入力データ (土裹特性, 施肥暦, 気象及 びセンサーデータ）の表示と出力

(2)過去の施肥に由来する今後のセンサー部 位における予测窒素濃度の表示及び出力

(3)今後の施肥に由来する施肥後のセンサー 部位における予測窒素濃度の表示及び出力

図 6 に開発した施肥管理ソフトフロチャー トを示した。

このように, 土袞の種類 ( 3 種類), $\mathrm{pH}$ ( 3 種類）さらに透水性（ 5 段階）について 45 の 組み合わせの中から該当するほ場を特定した 後, 肥料 ( 8 種類), 施用時期及び施用量を入 力すれば土裹中での無機化, 硝酸化成さらに

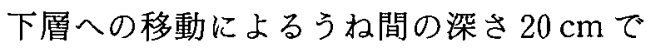
の窒素濃度の推移の予測が可能となった。

さらに, 施用した肥料毎の窒素成分の推移, それらの窒素成分の合量である無機態窒素濃 度推移とその時期の茶樹の目標窒素濃度とを

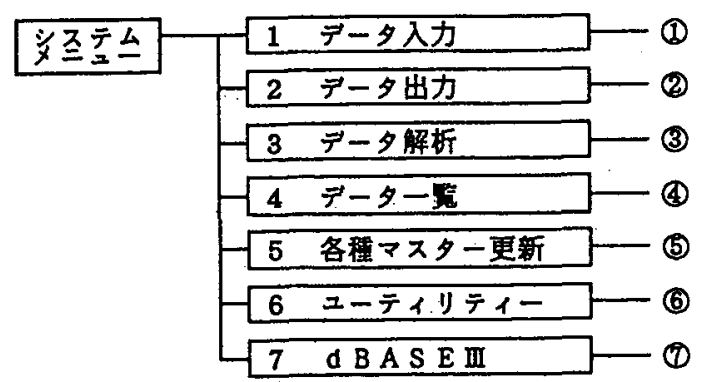

1 システムメニューフロチャート

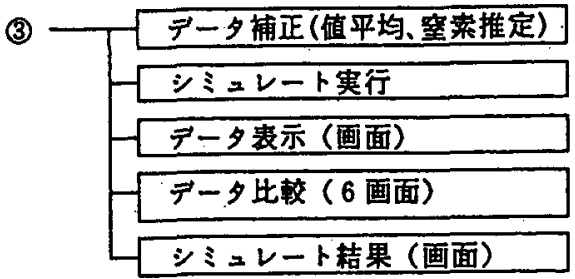

3 データ解析フロチャート
画面上で比較することにより肥料の種類, 施 肥時期, 施用量の判断による施肥管理が可能 となった。このようにして土珡埋設型セン サ一類, データロガ, パソコン及び施肥管理 ソフトからなる施肥管理システムを構築し た。

図 7 に施肥管理システムにより施肥の時 期, 肥料の種類及び量を決定する過程を春肥 を例に示した。まず，春肥の施用にあたり， 今後このまま施用しない場合のうね間哚さ $20 \mathrm{~cm}$ での窒素濃度の推移をシミュレートす る。この場合， 2 月末には目標窒素濃度を下 回ることが推定されるため，作業日程を考慮 し，2月 25 日を施肥日と定め，春肥として魚 粕中心の配合肥料を使用した。次に, 配合肥 料を 10 a あたり $100,150,200 \mathrm{~kg}$ と施用量を 変えて今後の土壌中の無機態窒素濃度をシ ミュレートしたところ，最も目標窒素濃度に 適合するのは $150 \mathrm{~kg}$ 施用であると判断され た。このようにして, 適宜に目標窒素濃度を 維持するようにシミュレートし,肥料の種類, 施用量及び施肥時期を決定し，年間の施肥管 理を行なった。

以上の結果, 各種センサーの情報によって

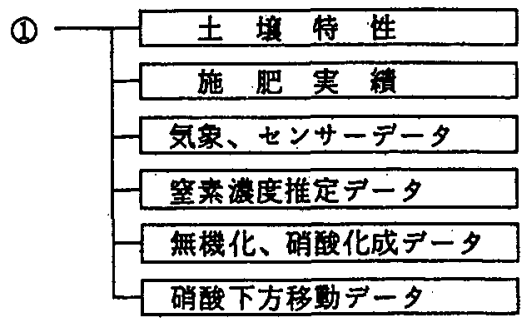

2 データ入カフロチャート

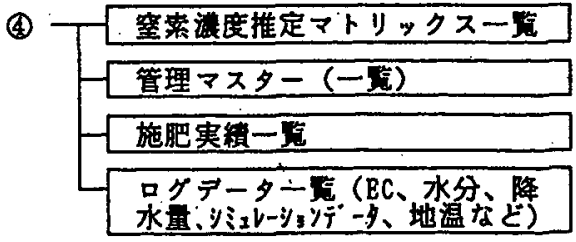

4 データー監フロチャート

図 6 施肥管理ソフトフロチャート 
土壌中窒素濃度をリアルタイムに把握し, 目 標窒案濃度を維持するための施肥の時期, 肥 料の種類及び量の判断が可能な施肥管理ソフ トのシミュレート結果に基づく茶園の施肥管 理が可能となった。

\section{5 土壤埋設型センサーによる施肥管理 実用化技術の実証 ${ }^{8,9)}$}

このシステムに基づいた目標窒素濃度に合 わせた施肥管理を, 静岡県茶試場内の赤黄色 土茶園及び黒ボク土茶園において実施し，施 肥量, 生葉の収量, 品質などに及ほす影響に ついて検討した。

施肥管理システムを利用した実証区と慣行 施肥区について，1991 年から 3 年間試験を 行った。1992 年の赤黄色土茶園での春肥の一 例を図 8 に示した。まず，春肥の施用にあた りパソコンによるうね間媣さ $20 \mathrm{~cm}$ での窒 素濃度の推移の予測を行い, 肥料の種類, 施 肥時期及び施肥量を変えてシミュレートさ

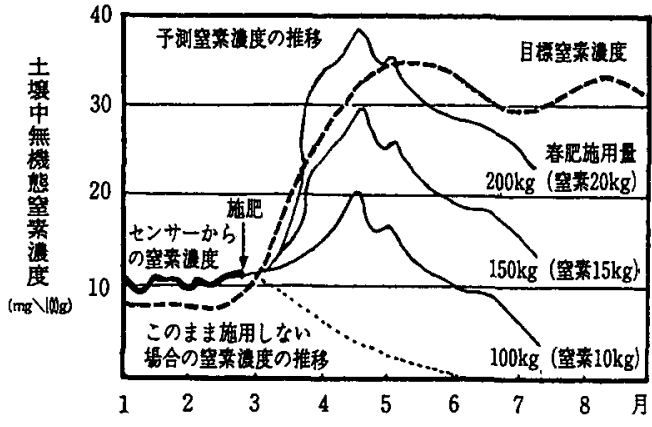

図 7 施肥管理システムによる施肥量決定の例

注 1 ) 肥料の種類、施用量、施肥時期を変えてうね間 (梁さ20cm) の窑紫濃度をパソコンでシュミレートし最適な施肥法を 決定する。

2) 図は2 月25日に春肥として配合肥料 (硝安、硫安、魚粕) を施用する場合のシュミレート結果である。

せ，いつの時期にどの様な肥料をどの程度施 用するかを判断した。この結果に基づき春肥

（I）は 2 月 10 日に硝安を 10 アール当り 29

無機態窒素量分析

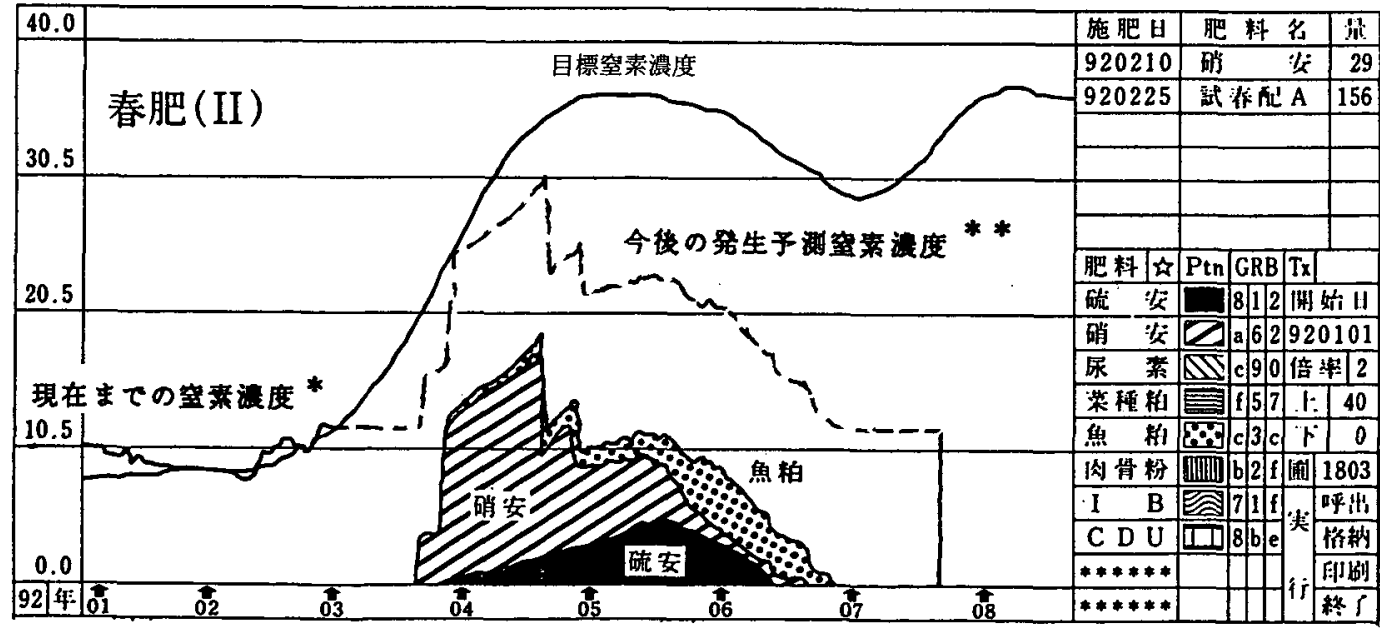

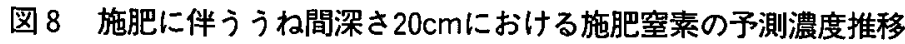

注）春配含 $\mathrm{A}$ 組成：硝安、硫安、魚粕（各々窒素成分を $3.2 \%$ 含有） 赤黄色土茶園

* : 1992年 4 月24日までのセンサーデータからの推定窒素濃度

**：1992年 4 月25日〜 7 月18日までのうね間深さ $20 \mathrm{~cm}$ の゙窒甞予測濃度の推移 
表 2 施肥状況（赤黄色土茶園）

\begin{tabular}{|c|c|c|c|c|c|c|c|c|c|}
\hline \multirow{3}{*}{ 年 度 } & \multirow{3}{*}{ 施肥回数 ${ }^{1\rangle}$} & \multicolumn{3}{|c|}{ 証 区 } & \multicolumn{5}{|c|}{ 慣 行 施 肥 区 } \\
\hline & & & 量 $(\mathrm{kg} / 1$ & & \multirow{2}{*}{ 施肥回数 } & \multicolumn{4}{|c|}{ 施肥量 $(\mathrm{kg} / 10 \mathrm{a})$} \\
\hline & & 窒 素 & リン酸 & カリ & & 窒 素 & リン酸 & カ & リ \\
\hline 1991 & 8 & 86 & 23 & 52 & 11 & 118 & 40 & 7 & \\
\hline 1992 & 9 & 74 & 28 & 42 & 11 & 118 & 40 & 7 & \\
\hline 1993 & 9 & 86 & 26 & 37 & 11 & 118 & 40 & 7 & \\
\hline 平均 & 8.7 & 82 & 26 & 44 & 11 & 118 & 40 & 7 & \\
\hline
\end{tabular}

注）苦土石灰の施用は除く

$\mathrm{kg}$, 春肥 (II) は 2 月 25 日に配合肥料（窒菜 成分で硝安，硫安，魚粕，各々 $3.2 \%$ 含有)を $156 \mathrm{~kg}$ (窒素 $15 \mathrm{~kg} / 10 \mathrm{a}$ ) 施用した。夏肥以 降の施肥管理についても，同様にパソコンの 予測分析による施肥管理を続けた。

試験期間中の施肥状況を表 2 に示した。慣 行施肥区では毎年, 10 a 当り窒素, リン酸, カリ各々 $118,40,79 \mathrm{~kg}$ を 11 回に分けて施用 した。一方, 実証区での施肥量及び施肥回数 は, 窒素成分として 10 a 当たり 1991 年は 86 $\mathrm{kg}-8$ 回, 1992 年は $74 \mathrm{~kg}-9$ 回, 1993 年は 86 kg- 9 回であり, 平均施用量は $82 \mathrm{~kg}$, 施肥回 数は 8.7 回であった。このように施肥管理シ ステムによる管理では施肥回数, 施肥量共に 慣行施肥区に比べて減少した。

赤黄色土茶園に抢ける 1992 年の土壤中無 機態公素濃度の推移をみると慣行施肥区では 3 月に入ると高まり，4 月下旬に $48 \mathrm{mg} / 100$ $\mathrm{g}$ となり, 以後 9 月中旬まで $45 \mathrm{mg}$ 以上の濃 度を維持した後, 漸減した。実証区 (窒素 74 $\mathrm{kg} / 10 \mathrm{a})$ では 3 月に入ると濃度の急激な上 昇が認められ 4 月上旬に $40 \mathrm{mg}$ と最も高く なり, 以後 10 月中旬まで $30 \mathrm{mg}$ 以上の濃度 で推移した後, 少しづつ減少した。実証区で は慣行施肥区に比べて年間を通じて概ね 10〜15 mg 程度低く推移した。(図表略)

これらのことから, 今後, 目標窒素濃度の 見直しやセンサーを埋設部位や深さを変えて 設置し，根圏全体の把握による施肥管理を行 なうことにより，さらなる施肥量の削減が可 能と考えられた。
赤黄色土茶園における一番茶の生葉収量は 慣行施肥区の 1992 年で減収となったが，3 年 間の平均では実証区は $10 \mathrm{a}$ 当たり $547 \mathrm{~kg}$, 慣行施肥区は $551 \mathrm{~kg}$ であり, 二番茶では平均 で実証区 $390 \mathrm{~kg}$, 慣行施肥区 $400 \mathrm{~kg}$ と両処 理区間は差は認められなかった。

(図表略)

官能審查による製茶品質は外観，内質とも に, 各年一番茶, 二番茶ともに区間で差は認 められなかった。(図表略)

新芽の全窒素濃度は一番茶, 二番茶共に, 区間での濃度の差は認められなかった。この ように実証区と慣行施肥区の間で生育, 収量 及び品質において差は認められなかった。

以上の結果，開発した施肥管理システムを 利用し目標窒素濃度を維持する管理を行なう ことにより, 慣行施肥区に比べ少ない施肥量 で同等の収量, 品質を得ることができた。

\section{6 おわりに}

この施肥管理システムの導入により, 農家 が簡便にしかもリアルタイムに土壤中の無機 態窒素濃度の把握ができると共に，パソコン を利用して適切な施肥時期, 施肥量を計算し, 農家自身の判断による施肥管理を行なうこと により施肥量の削減が可能となり農家の経営 安定に寄与するものと考える。このシステム は開発後, 静岡県下の 2 メーカーにより, 操 作性の向上, 演算速度の短縮化, 太陽電池を 利用した自動計測と無線によるデータの発受 信など大幅な改良がなされている。本県では 
平成 6 年度に, 開発した施肥管理システムを 国庫補助金を導入した補助事業の対象とし, 現在まで, 普及所, 茶農協, 経済連を中心に 設置が広がっている。また，設置したほ場で の施肥管理のみならず，普及センタ一，農協 などにおけるパソコン利用による農家への適 確なる施肥指導, さらに, 年間のシミュレー トによる施肥設計の構築に利用され具体的な 施肥量の削減が広がりつつある。

今後ますます茶園からの環境負荷軽減が強 く求められると考元るが，このシステムに関 して今後検討しなければならない問題点は少 なくない。例えば，(1)無機態窒素濃度計測精 度の向上：EC センサーは土畩溶液の硝酸態 至素だけでなく硫酸, 塩素, 石灰や苦土など の他のイオンも同時に計測している。茶園で は窒素肥料の多肥による窒素成分の組成が大 きいため EC との相関が高いという面もあ り, 目的とする無期態窒素濃度の計測精度を 更に高めるため，他成分の計測による補正等 の検討が必要である。(2) EC センサー使用方 法の改善：センサーをうね間の梁さ $20 \mathrm{~cm}$ に埋設するため,アンモニア態窒素の検出感 度は小さい。アンモニア態窒素の吸収効率を 高めるための施肥管理とそれに伴う部位や深 さなどについてセンサー使用方法の改善が必 要と考える。また, 茶園全体の代表 EC 值把握 の精度改善のためにセンサーの計測接地面積 拡大も一つの方法である。(3)施肥管理システ ムのメンテナンスの簡易化：ECセンサー は, センサー基常值のチェック,ケーブルの 獣による断線対策や 3 个月毎にセル常数補正 の簡素化などの改良が求められている。(4)策 定した目標窒素濃度の見直しによる最適窒素 濃度の解明, (5)設置した地域間のデータや効 果に関する情報交換, 更に(6)県下の主要な地 点間のネットワークによる情報交換と発信, (7)多肥栽培がなされている他の作物への適応
性等が残されており，今後検討していかなけ ればならないと考える。

これら一連の研究は地域重要新技術開発促 進事業 (主查県: 静岡県, 共同県: 神奈川県, 岐皁県, 1989 年〜1992 年)で奉施したもので あり, 研究方向の検討以来, 日常の研究で良 きパートナーとして助けていただいた栽培研 究室の森田明雄, 鈴木則夫の両氏, その他多 くの関係者の方々に厚く感謝いたします。

\section{7 引用 文 献}

1) 岩橋光育 (1992)：土壤埋設型センサーを 利用した茶園土壌の無機態窒素, 静岡茶 試研報 $16 ， 35 \sim 41$

2 ）農水省農虫園芸局 (1979)：土壌，水質及 び作物体分析法：1 2

3）岩橋光育 (1994)：土壌埋設型センサーの 埋設方法, 静岡茶試研報 $18,43 \sim 46$

4) 田中和夫(1987)：固形培地新素材および センサの開発, 農業及び園芸 62 , $111 \sim 118$

5 ）柳沢宗男・高橋治助 (1959)：作物の試料 採取方法に関する研究，土肥誌 30 , $297 \sim 301$

6 ）岩橋光育・森田明雄（1996）：黒ボク土裹 における透水性と有機物混合率の違いが 窒素成分の移動に及ぼす影響，茶研報 84 , 投稿中

7 ）鈴木則夫 (1996)：有機質肥料施用茶園の 地力窒素の評価, 静岡茶試研報 20,1 $\sim 6$

8）岩橋光育 (1989)：土袞埋設型センサーの 情報による茶園の施肥管理, 土肥誌講演 要旨集 35,323

9 ）岩橋光育・鈴木則夫・森田明雄（1995）: 土䱪埋設型センサーを利用した施肥管理 システムによる施肥管理, 静岡茶試研報 $19,49 \sim 58$ 